\title{
NILAI CITRA KOTA DARI SUDUT PANDANG WISATAWAN (Studi Tentang Citra Kota Bandung Dampaknya Terhadap Kunjungan Ulang)
}

\author{
Didin Syarifuddin \\ ARS International School of Tourism \\ didinars@yahoo.com
}

\begin{abstract}
ABSTRAK
Bandung dikenal dengan sebutan Kota Kembang, Paris Van Java, dan Kota Konferensi Asia Afrika. Sebutan tersebut menggambarkan Bandung memiliki citra kota dengan kesan positif dari wisatawannya. Namun citra tersebut relatif sudah mulai bergeser, sehingga dukungan terhadap citra kota dalam bentuk menurunnya rasa sejuk pada lingkungan alamnya, memudarnya warga Bandung yang "someah hade ka semah", berdampak pada menurunnya tingkat keramahannya, tingkat kemacetan yang cukup tinggi dengan sarana dan prasarana transportasi yang belum memadai berdampak terhadap tingkat kunjungan ulang dan menjadikan Bandung berbeda dari sebelumnya. Tujuan penelitian ini adalah untuk menjelaskan Citra Kota Bandung dalam dukungan cognitive, unique, dan affective image dampaknya terhadap kunjungan ulang wisatawan, menggunakan analisis jalur dengan ukuran sampel 100 orang. Hasil penelitian menunjukkan bahwa Citra Kota Bandung yang dibangun melalui tingkat variasi atraksi wisata, lingkungan sosial budaya dengan tradisi lokal yang diwujudkan dalam bentuk ramah terhadap tamunya gambaran memuliakan wisatawan, dukungan infrastruktur yang cukup memadai sebagai daya dukung kepariwisataan, aneka jenis hiburan tradisional dapat memberikan kesan positif bagi pengalaman wisatawan sehingga menjadi faktor penentu kunjungan ulang. Lingkungan alam kota Bandung masih cukup memberikan kesejukan dan atraksi budaya lokal yang bernilai Internasional memberikan kesan yang sangat baik sehingga membangkitkan kunjungan ulang. Terbangunnya kunjungan ulang sebagai dampak dari pengalaman wisatawan yang dirangkum dari pengetahuan selama melakukan kunjungan, menumbuhkan ketertarikan sehingga membangkitkan keinginan wisatawan untuk melakukan kunjungan ulang.
\end{abstract}

Kata kunci: Citra Kota, Cognitive Image, Unique Image, Affective Image, Repeat Visit.

\section{ABSTRACT}

Bandung is known as The Flower City, Paris Van Java, and the City of the Asian-African Conference. The title describes Bandung has a city image with a positive impression from its tourists. However, this image has begun to shift relatively, so that support for the image of the city in the form of a decreased sense of coolness in its natural environment, waning Bandung residents who "someah hade ka semah", have an impact on the decreasing level of hospitality, a high level of congestion with transportation facilities and infrastructure inadequate impact on the level of repeat visits and making Bandung is different from before. The purpose of this study is to explain the city image of Bandung in terms of cognitive, unique, and affective image of its impact on tourist visits, using path analysis with a sample size of 100 people. The results showed that City Image of Bandung, built through a variety of tourist attractions, a socio-cultural environment with local traditions embodied in a friendly form towards its guests, illustrated glorifying tourists, adequate infrastructure support as tourism support, various types of traditional entertainment can give a positive impression for tourists' 
experience so that it becomes a determining factor for repeat visits. The natural environment of Bandung is still sufficient to provide coolness and local cultural attractions of international value give a very good impression that evokes repeat visits. Rebuilding visits as a result of the experience of tourists summarized from the knowledge during the visit, fostering interest so as to arouse the desire of tourists to make a repeat visit.

Keywords: City Image, Cognitive Image, Unique Image, Affective Image, Repeat Visit.

\section{PENDAHULUAN}

Pariwisata merupakan komoditas utama dalam format pembangunan sebuah wilayah, termasuk pembangunan sebuah Kota, sehingga sangat wajar apabila pariwisata telah menjadi "sang primadona" tumpuan pembangunan ekonomi masyarakat dalam meningkatkan kesejahteraannya (Syarifuddin, 2016). Sebagai tumpuan pembangunan ekonomi masyarakat, maka pariwisata sangat erat terkait dengan kepentingan (1) masyarakat sebagai sasaran pembangunan yang berhak mendapatkan kesejahteraan; (2) pemerintah sebagai pelayan masyarakat; (3) pengelola pariwisata sebagai pelayan wisatawan yang akan menikmati kunjungannya; dan (4) masyarakat yang berhak atas dampak positif perkembangan ekonomi sebagai multi player effect atas pembangunan pariwisata (Syarifuddin, 2018). Sangat jelas bahwa berbicara pariwisata berarti berbicara kepentingan masyarakat yang di dalam penyediaan sarana dan prasarana harus disiapkan oleh pengelola destinasi maupun oleh pemerintah, terkait dengan aspek ketersediaan jalan, transportasi, bandara, air bersih dan sejenisnya.

Arah pembangunan sebuah kota akan erat terkait dengan pembangunan pariwisatanya atau arah pembangunan pariwisata akan erat terkait dengan pembangunan kotanya. Semakin tinggi tingkat kepedulian pemerintah terhadap pembangunan kotanya, maka akan semakin tinggi pula peluang untuk dapat meningkatkan pembangunan pariwisatanya sehingga dapat memberikan layanan kepada tamunya. Dalam konteks ini ada benefit finansial bagi masyarakat, artinya apabila ingin membangun masyarakat, maka harus dapat membangun kotanya.

Berbicara pariwisata tidak bisa lepas dari berbicara faktor pendukung yang berlabel tiga F yaitu fun, food, dan fashion, yang menjadi kebutuhan pokok para wisatawan (Syarifuddin, 2017). Wisatawan ingin mendapatkan sesuatu yang lebih atas kunjungannya. Tingginya tingkat harapan wisatawan berdampak pada pergeseran pemaknaan masyarakat terhadap kunjungan yang dilakukannya sehingga kunjungan telah menjadi suatu gaya hidup (Marketing Outlook, 2016). Ketika kebutuhan terhadap fun telah menjadi suatu gaya hidup, maka dapat dijadikan sebagai peluang baru yang bisa dilakukan oleh sebuah kota untuk mendatangkan wisatawan sebanyakbanyaknya, karena akan memberikan devisa setinggi-tingginya bagi kota yang dikunjunginya.

Sebagai Ibu Kota Provinsi, Bandung dikenal sebagai Kota dengan sejuta sajian kuliner yang menarik, atraksi wisata tradisional yang berkelas Internasional, seperti Saung angklung Udjo, lingkungan sosial budaya yang "someah hade kasemah", sangat menghormati tamunya, citra kota dengan sebutan Paris Van Java, Kota Konferensi Asia Afrika dan Kota Kembang. Hal lain yang memberikan kesan baik terhadap Kota Bandung adalah lingkungan alam Kota Bandung. Kota Bandung sebagai kota seni budaya dan tujuan wisata dengan kekhasannya, memiliki daya tarik tersendiri bagi para pengunjung. Tumbuhnya energi kreatif telah membuat Kota Bandung berbeda. Kota Bandung diakui memiliki keunikan strategis dengan potensi dan keragaman wisata alam dan budaya. 
Masyarakat Bandung mendapatkan berkah atas lingkungan alam yang indah, dengan berbagai keragaman kreativitas masyarakatnya. Kota Bandung terletak bagaikan berada di dasar lengkungan yang dikelilingi oleh barisan pegunungan yang kokoh dengan budaya lokal dalam wujud keramahan kepada para tamunya. Ini pula yang menjadi kelebihan Bandung dengan kekayaan budaya dan keunikan kearifan lokalnya.

Populasi Kota Bandung adalah 2.490.622 orang pada Tahun 2016. Bandung menjadi salah satu Kota yang paling padat di Indonesia. Pada sisi lain, tingkat kunjungan wisatawan ke Kota Bandung, untuk wisatawan Mancanegara sebanyak 173.036 orang dan wisatawan Domestik sebanyak 4.827.589 orang, totalnya 5.000.625 orang (Dinas Kebudayaan dan Pariwisata Kota Bandung, Tahun 2016). Jumlah wisatawan yang berkunjung ke Bandung melebihi jumlah penduduknya dengan hampir dua kali lipat. Sementara kesiapan Pemerintah Kota Bandung dalam memberikan pelayanan terutama aspek transportasi belum maksimal dengan tingkat traffic jam yang sangat tinggi, sehingga untuk menjangkau satu destinasi akan membutuhkan waktu yang cukup lama.

Permasalahan lain Kota Bandung adalah keindahan alam berupa taman kota yang kurang terpelihara, bahkan sempat ada upaya dari pemerintah kota untuk menggantikan taman kota Babakan Siliwangi menjadi Bangunan Mal (Hasil Wawancara Tahun 2013). Pembangunan mal yang tidak seimbang jumlahnya antara di wilayah Utara, Barat, Selatan dan Timur. Atraksi wisata yang sudah mendunia dari Saung Angklung Udjo belum gebyar diikuti oleh atraksi yang lainnya. Keunikan kota juga mulai pudar, terutama pada aspek Bandung sebagai kota yang sejuk, karena saat ini udara di Kota Bandung untuk daerah Selatan dan Tengah sudah panas. Aspek budaya lokal dalam pertunjukkan seni budaya tradisional, seperti Benjang, Reak, dog-dog dan lainnya kurang begitu diminati masyarakat, sehingga berdampak pada minimnya pementasan seni tersebut. Ujungnya adalah kesempatan bagi wisatawan untuk menikmati pementasan seni budaya tersebut, jarang terjadi (hasil wawancara Pak Endin, Cinunuk 5 April 2014).

Permasalahan citra kota seperti disampaikan di atas dimungkinkan berdampak pada kunjungan ulang wisatawan ke kota Bandung, seperti pada tabel 1, berikut.

\section{Tabel 1. Data Kunjungan Wisatawan Ke}

Kota Bandung Tahun 2011 - 2017

\begin{tabular}{ccccc}
\hline Tahun & $\begin{array}{c}\text { Wisatawan } \\
\text { Mancanegara }\end{array}$ & $\begin{array}{c}\text { Wisatawan } \\
\text { Nusantara }\end{array}$ & $\begin{array}{c}\text { Jumlah } \\
\text { (orang) }\end{array}$ & $\%$ \\
\hline 2011 & 225.585 & 6.487 .239 & 6.712 .824 & - \\
\hline 2012 & 176.855 & 5.080 .584 & 5.257 .439 & $-22 \%$ \\
\hline 2013 & 176.432 & 5.388 .292 & 5.564 .724 & $+6 \%$ \\
\hline 2014 & 180.143 & 5.627 .421 & 5.807 .564 & $+4 \%$ \\
\hline 2015 & 183.932 & 5.877 .162 & 6.061 .094 & $+4.4 \%$ \\
\hline 2016 & 173.136 & 4.827 .589 & 5.000 .625 & $-17.5 \%$ \\
\hline 2017 & 432.271 & 1.431 .290 & 1.863 .561 & $-63 \%$ \\
\hline
\end{tabular}

Sumber: Dinas Kebudayaan dan Pariwisata Kota Bandung Tahun 2018

Tabel 1 menggambarkan bahwa jumlah kunjungan wisatawan Nusantara maupun Mancanegara ke Kota Bandung mengalami tingkat fluktuasi yang cukup berarti. Pada Tahun 2012, 2016 dan Tahun 2017 mengalami penurunan jumlah wisatawan yang cukup signifikan, bahkan pada Tahun 2017 jumlah kunjungan wisatawan Nusantara ke Kota Bandung turun sangat signifikan tercapai sebesar 63 persen, kalaupun di saat yang sama mengalami kenaikan pada wisatawan Mancanegara sebesar 150 persen. Sementara pada Tahun 2013, 2014 dan 2015 mengalami kenaikan dengan tingkat kenaikan yang tidak signifikan.

Berdasarkan permasalahan tersebut, maka dianggap tepat untuk melakukan penelitian dengan tema "Nilai Citra Kota dari Sudut Pandang Wisatawan melalui analisis dampak aspek cognitive image, unique image dan affective image sebagai citra kota terhadap aktivitas kunjungan ulang wisatawan ke Kota Bandung". 


\section{LANDASAN TEORI}

\section{Citra Kota}

Citra adalah sesuatu yang abstrak yang hanya dapat dirasakan dari hasil penilaian baik atau buruk melalui tanggapan positif maupun negatif dari masyarakat. Berbicara citra akan berbicara sesuatu yang diperoleh dalam bentuk informasi yang menjadi pengetahuan selama melakukan kunjungan di destinasi, artinya bahwa citra merupakan persepsi seseorang atas kunjungan yang telah dilakukannya. Sehingga dapat disampaikan bahwa citra merupakan output dari pikiran tentang informasi yang diperolehnya berupa pesan.

Segala sesuatu yang berkaitan dengan aktivitas yang terjadi di kota sebagai sebuah "teritori" akan berkaitan dengan orang yang tinggal di kota tersebut mengkomunikasikan citra dari suatu tempat yang dianggap penting, untuk mempengaruhi orang lain tentang citra kota yang ditinggalinya. Citra bergantung pada setiap orang yang menghubungkannya dengan wilayahnya. Sementara kota merupakan kawasan pemukiman yang secara fisik ditunjukkan oleh kumpulan rumah-rumah yang mendominasi tata ruangnya dan memiliki berbagai fasilitas untuk mendukung kehidupan warganya secara mandiri.

Memadukan beberapa pendapat di atas dapat disampaikan bahwa citra kota merupakan persepsi seseorang tentang hasil kunjungannya dalam bentuk penilaian baik atau buruk melalui tanggapan positif maupun negatif sebagai persepsinya ke sebuah kota yang dianggap penting dan bersifat abstrak untuk disampaikan kepada orang lain.

Citra yang terdapat pada suatu destinasi wisata dikenal dengan istilah citra destinasi. Menurut (Martinez, et all. 2010) bahwa citra destinasi merupakan kesan wisatawan terhadap suatu destinasi wisata. (Hailin Qu, et all. 2016) menyatakan bahwa citra destinasi secara psikologis merupakan penyimpanan informasi dalam memori berupa bau, rasa, penglihatan, suara dan sentuhan pada suatu destinasi wisata.
Berdasarkan penjelasan tentang citra kota, dapat disampaikan bahwa citra kota adalah gambaran hasil semua panca indera yang tersimpan terhadap destinasi wisata dan dapat dijadikan acuan dalam pengambilan keputusan untuk berwisata.

Bagaimana mengukur citra kota. (Hailin Qu, et all 2016) mengungkapkan bahwa citra destinasi terdiri dari tiga dimensi: 1) Dimension of cognitive destination image (quality of experiences, touristic atraction, environtment and infrastrtucture, entertainment/outdoor activities and cultural traditions). 2) Dimension of uniqe destination image (natural environtment, appealing destination, and local atraction. 3) Dimension of affective destination image (pleasat, arousing, relaxing, and exciting).

Cognitive image didapat dari kualitas pengalaman, atraksi wisata di destinasi, lingkungan dan infrastruktur, hiburan dan tradisi budaya. Unique image terdiri dari lingkungan alam, kemenarikan suatu destinasi dan atraksi lokal yang ada di destinasi tersebut. Affective image terdiri dari perasaan yang menyenangkan, membangkitkan, santai dan menarik ketika berada di suatu destinasi.

\section{Perilaku Pasca Berkunjung}

Menurut (Kotler dan Keller, 2012), ada tiga langkah yang menyangkut perilaku pasca pembelian:

1. Kepuasan Pasca Pembelian

Kepuasan pasca pembelian adalah fungsi harapan dibandingkan dengan kinerja produknya.

2. Tindakan Pasca Pembelian

Kepuasan atas produk yang dikonsumsinya akan mempengaruhi perilaku selanjutnya. Jika konsumen merasa puas, selanjutnya konsumen akan menunjukkan kemungkinan yang lebih tinggi untuk kembali membeli produk tersebut.

3. Penggunaan Kembali Pasca Pembelian Tingkat kepuasan konsumen merupakan suatu fungsi dari keadaan produk yang sebenarnya dengan keadaan produk yang diharapkan. Rasa puas akan 
mempengaruhi konsumen untuk melakukan pembelian berikutnya.

Berdasarkan pengertian di atas dapat disampaikan bahwa perilaku pasca berkunjung adalah perilaku setelah merasakan kepuasan pasca berkunjung, tindakan pasca berkunjung dan kecenderungan untuk datang kembali. (Kotler dan Keller, 2012) menjelaskan bahwa terdapat tiga komponen dalam kunjungan ulang yaitu kepuasan pasca pembelian, tindakan pasca pembelian dan pemakaian pasca pembelian, yang selanjutnya dijadikan dimensi dalam penelitian ini dengan penyesuaian menjadi kepuasan setelah berkunjung; kepuasan setelah merasakan berbagai kegiatan dan keinginan melakukan kunjungan ulang.

Citra kota merupakan aspek penting bagi wisatawan untuk melakukan kunjungan ulang. Echter dan Ritchie mengungkapkan bahwa citra kota berperan penting dalam memahami perilaku wisatawan dalam melakukan perjalanan (Echter dan Ritchie, 2003). Jenkins mengatakan bahwa citra akan berkaitan dengan kesan, pengetahuan, emosi, nilai dan benefit dan dengan perilaku konsumen (Jenkins, 2009). Keterkaitan citra dengan kesan, pengetahuan, emosi, nilai dan benefit, keduanya saling menguatkan bahwa citra berhubungan dengan pengetahuan, kesannya, nilai yang diperolehnya, serta keuntungan yang dirasakannya, yang dapat menentukan perilakunya dalam bentuk kunjungan ulang.

Jenkins (2009) menyatakan "Tourist destination images are important because they influence both the decision $\neg$ making behavior of potential tourists and the levels of satisfaction regarding the tourist experience" (Jenkins, 2009). Citra destinasi wisata dianggap penting karena dapat menentukan keputusan wisatawan atas kepuasan selama berkunjung.

Banyai menyampaikan bahwa "note that images are of paramount importance to destinations because they have the power to change and re-arrange the tourists' impressions and perceptions of a destination and "give him or her a pre-taste of the destination" (Banyai, 2009). Keterkaitan citra kota dengan keinginan berkunjung ulang dengan memaknai citra kota dengan kekuatannya dapat berperan besar untuk mengubah dan mengatur kembali kesan dan persepsi wisatawan di dalam menentukan destinasi yang akan dikunjungi. Berikut disampaikan paradigma penelitian.

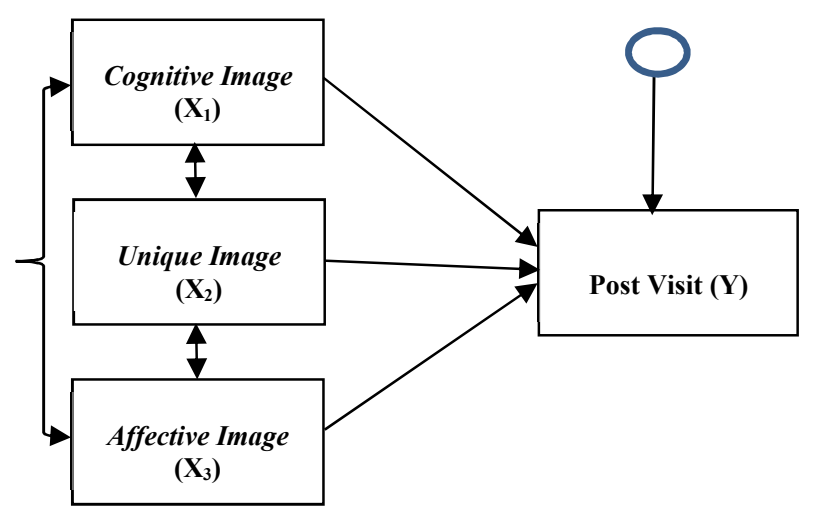

Gambar 1. Paradigma Penelitian

\section{METODE}

Penelitian ini menggunakan metode survei eksplanatori untuk menjelaskan hubungan kausal antara variabel citra kota dalam dukungan cognitive image, unique image, dan affective image dengan variabel keputusan berkunjung ulang baik secara parsial maupun secara simultan melalui pengujian hipotesis (Singarimbun, 2004). Populasi penelitian adalah wisatawan yang datang ke Kota Bandung dengan ukuran sampel 100 orang. Telaah statistika model struktural dipandang tepat untuk menjelaskan penelitian ini, karena dapat mengungkapkan hubungan kausalitas dari variabel pengaruh terhadap variabel terpengaruh, baik secara parsial maupun secara simultan (Al Rasyid, Harun, 2005). Teknik pengumpulan data melalui penyebaran kuesioner dan studi pustaka. Uji statistika dilanjutkan dengan uji hipotesis dengan menggunakan Program AMOS 5.

\section{HASIL DAN PEMBAHASAN}

Hasil analisis statistika terhadap variabel penelitian untuk menentukan besarnya pengaruh citra kota dalam 
dukungan cognitive image $\left(\mathrm{X}_{1}\right)$, unique image $\left(\mathrm{X}_{2}\right)$, dan affective image $\left(\mathrm{X}_{3}\right)$ terhadap keputusan berkunjung ulang ke Kota Bandung, ditampilkan pada gambar 2, di bawah ini.

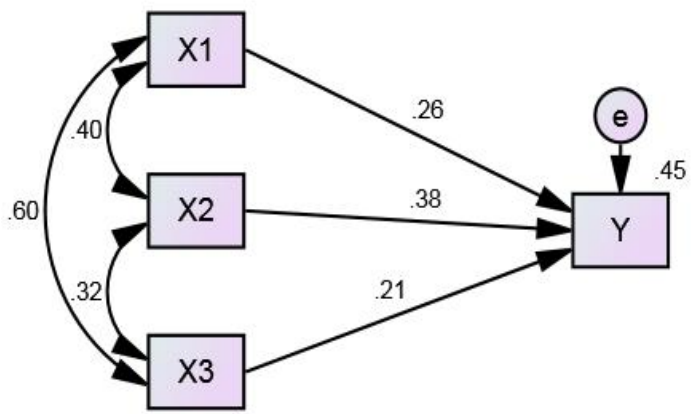

\section{Gambar 2. Hasil Analisis Amos Jalur Tahun 2018}

Gambar 2 di atas menunjukkan bahwa besarnya pengaruh citra kota dalam dukungan cognitive, unique dan affective image terhadap kunjungan ulang adalah 45 persen. Besarnya pengaruh ini adalah total dari pengaruh langsung masing-masing jalur dan pengaruh tidak langsung melalui $\mathrm{X}_{2}$ dan $\mathrm{X}_{3}$ dari $\mathrm{X}_{1}$, melalui $\mathrm{X}_{1}$ dan $\mathrm{X}_{3}$ dari $\mathrm{X}_{2}$ dan melalui $\mathrm{X}_{1}$ dan $\mathrm{X}_{2}$ dari $\mathrm{X}_{3}$ terhadap $\mathrm{Y}$. Koefisien jalur untuk masing-masing jalur menunjukkan nilai positif, artinya dukungan cognitive, unique dan affective image secara parsial maupun secara besama-sama sangat menentukan keberhasilan kunjungan ulang. Nilai positif menunjukkan tinggi rendahnya pengalaman berkunjung dengan kesan citra kotanya dalam dukungan masing-masing cognitive, unique dan affective image sangat menentukan tinggi rendahnya tingkat kunjungan ulang.

Untuk memberikan kemudahan dalam memahami besarnya pengaruh dari masingmasing variabel eksogenus terhadap variabel endogenus, disampaikan pada tabel 2 di bawah ini.

\begin{tabular}{|c|c|c|c|c|}
\hline PENGARUH ANTAR VARIABEL & NILAI & $(\%)$ & C.R. & RANK \\
\hline 4) PENGARUH $X_{1}, X_{2}$ DAN $X_{3}$ THD $Y$ & 0.4500 & 45.00 & $26.331>2.76$ & \\
\hline PENGARUH FAKTOR LAIN (E) THD Y & 0.5500 & 55.00 & Signifikan & \\
\hline 1) PENGARUH TOTAL $X_{1}$ THD $Y$ & 0.1400 & 14.00 & \multirow{4}{*}{$\begin{array}{c}2.709>1.667 \\
\text { Signifikan }\end{array}$} & \multirow{4}{*}{2} \\
\hline Pengaruh Langsung & 0.0676 & 6.76 & & \\
\hline Pengaruh Tidak Langsung Melalui $\mathrm{X}_{2}$ & 0.0396 & 3.96 & & \\
\hline Pengaruh Tidak Langsung Melalui $\mathrm{X}_{3}$ & 0.0328 & 3.28 & & \\
\hline 2) PENGARUH TOTAL $X_{2}$ THD $Y$ & 0.2095 & 20.95 & \multirow{4}{*}{$\begin{array}{c}4.647> \\
1.667 \\
\text { Signifikan }\end{array}$} & \multirow{4}{*}{1} \\
\hline Pengaruh Langsung & 0.1444 & 14.44 & & \\
\hline Pengaruh Tidak Langsung Melalui $\mathrm{X}_{1}$ & 0.0396 & 3.96 & & \\
\hline Pengaruh Tidak Langsung Melalui $\mathrm{X}_{3}$ & 0.0255 & 2.55 & & \\
\hline 3) PENGARUH TOTAL $X_{3}$ THD Y & 0.1024 & 10.24 & \multirow{4}{*}{$\begin{array}{c}2.235> \\
1.667 \\
\text { Signifikan }\end{array}$} & \multirow{4}{*}{3} \\
\hline Pengaruh Langsung & 0.0441 & 4.41 & & \\
\hline Pengaruh Tidak Langsung Melalui $\mathrm{X}_{1}$ & 0.0255 & 2.55 & & \\
\hline Pengaruh Tidak Langsung Melalui $\mathrm{X}_{2}$ & 0.0328 & 3.28 & & \\
\hline
\end{tabular}

Tabel 2 di atas memberikan gambaran bahwa pengaruh total citra kota dalam dukungan cognitive image, unique image, dan affective image terhadap keputusan berkunjung ulang adalah 45 persen. Besarnya pengaruh ini signifikan, artinya keberhasilan Pemerintah Kota Bandung dalam membangun citra kotanya sehingga memberikan pengalaman berwisata yang sangat baik dalam dukungan cognitive image, unique image, dan affective image bagi wisatawan sangat menentukan tingginya tingkat kepuasan dan kenyamanan yang dirasakan sehingga menumbuhkan keinginan wisatawan untuk melakukan kunjungan ulang ke Kota Bandung. Apabila melihat secara parsial bahwa aspek cognitive image, unique image dan affective image secara parsial sangat menentukan tingkat kunjungan ulang wisatawan ke Kota Bandung. 


\section{Cognitive Image Menentukan Kunjungan Ulang.}

Citra kota aspek kognitif adalah persepsi seorang wisatawan dari informasi yang diperolehnya selama melakukan kunjungan terhadap atraksi wisata baik berupa kesenian, daya tarik budaya, perilaku masyarakat, infrastruktur yang tersedia sebagai daya dukung keberhasilan pariwisata, hiburan serta tradisi masyarakat dalam wujud kebudayaan yang dilihatnya termasuk ke dalam kategori baik. Informasi yang diperoleh sebagai hasil analisis, evaluasi dan proses kesimpulan sehingga difahami dengan tepat dan menjadi pengalaman yang sangat berharga sebagai sumber pengetahuan baik bagi dirinya maupun bagi orang lain. Pengetahuan tersebut memberikan kesan dan pesan yang positif sebagai pengalaman atas kunjungannya, dan menentukan seorang wisatawan untuk melakukan kunjungan ulang. Kota Bandung mendapatkan citra yang positif dari wisatawannya karena telah dapat memberikan pengalaman dan pengetahuan yang berharga bagi para wisatawannya. Tingginya tingkat pengetahuan dan pengalaman tersebut sangat menentukan para wisatawan untuk melakukan kunjungan ulang ke Kota Bandung. Lebih jauh semakin tinggi Pemerintah Kota Bandung dapat memberikan layanan yang berdampak pada tingginya tingkat pengetahuan dan pengalaman para wisatawannya, maka semakin tinggi pula peluang bagi para wisatawan untuk melakukan kunjungan ulang dan sebaliknya.

\section{Unique Image Menentukan Kunjungan Ulang Wisatawan.}

Citra kota aspek unik adalah persepsi seorang wisatawan atas kunjungan yang telah dilakukan sehingga menjadi pengalaman terhadap lingkungan alam yang dirasakannya yang memberikan kesejukan dan rimbunnya pohon-pohon sehingga menjadi daya tarik tersendiri yang tidak dimiliki kota lain di Indonesia. Hal lain adalah daya tarik terhadap lingkungan sosial masyarakatnya dengan budaya yang unik dalam wujud "someah hade ka semah", sangat menghormati tamunya termasuk sangat menghormati wisatawan yang datang ke Kota Bandung. Atraksi budaya lokal yang ditunjukkan melalui pementasan kesenian yang bersifat tradisional dengan kualitas, popularitas dan daya tarik yang berskala Internasional, seperti pertunjukan "Saung Angklung Udjo". Keunikan yang lain adalah Bandung mendapatkan citra sebagai Paris Van Java, Bandung sebagai Kota Konfrensi Asia Afrika, dan Bandung sebagai Kota Kembang. Pada aspek lingkungan alamnya, bahwa hanya Kota Bandung yang memiliki Taman Hutan Raya dengan berbagai jenis tanaman yang dimilikinya. Kondisi keunikan ini hanya ada dan hanya dimiliki oleh Kota Bandung, artinya Kota lain di Indonesia "pada aspek ini", tidak memilikinya, sehingga dapat dikatakan Bahwa Kota Bandung, beda dengan kota lain di Indonesia. Keunikan inilah yang justru sangat menentukan para wisatawan untuk melakukan kunjungan ulang.

\section{Affective Image Menentukan Kunjungan Ulang Wisatawan. \\ Citra kota aspek afektif adalah} persepsi seorang wisatawan atas kunjungan yang telah dilakukannya sehingga memberikan kesan atas pesan yang diperolehnya, sikap atas hubungan sosial dengan masyarakat yang dijumpai, perasaan yang timbul atas kontak sosial yang terjadi, dan berdampak pada nilai yang dirasakannya. Nilai yang diperoleh para wisatawan berdampak pada kesan para wisatawan atas kunjungan ke Kota Bandung. Tingginya nilai yang dirasakan, sebagai gambaran tingginya tingkat kesan yang diterimanya, artinya para wisatawan mendapatkan kesan baik atas lingkungan alam yang dijumpainya, lingkungan sosial atas hubungan sosialnya, dan kontak sosial yang terjadi. Kota Bandung telah dapat menciptakan kesan positif bagi para wisatawannya, sehingga para wisatawan memiliki keinginan kembali untuk berkunjung ke Kota Bandung. 
Citra Kota Menentukan Kunjungan Ulang Wisatawan. Citra kota merupakan aspek penting bagi wisatawan untuk melakukan kunjungan ulang. Tingginya tingkat pengalaman sebagai dampak dari tingginya tingkat daya Tarik wisata yang bervariasi; ditunjang dengan lingkungan sosial budaya masyarakatnya yang ramah dan kooperatif terhadap pengunjung; disamping ketersediaan infrastruktur yang memadai yang dapat mendukung kegiatan kepariwisataan; aspek hiburan yang disuguhkan dengan aneka tradisi budaya lokalnya dapat memberikan berbagai kenyamanan dan kepuasan atas kunjungannya, sehingga dampaknya adalah tumbuhnya keinginan wisatawan untuk melakukan kunjungan ulang. Aspek lain dari Tingginya tingkat kesejukan sebagai dampak dari lingkungan alam yang ditumbuhi dengan banyak pepohonan khususnya di wilayah Bandung Utara dapat memberikan kesan yang sangat baik bagi para wisatawan, sehingga Bandung menjadi kota yang menarik untuk dikunjungi; serta lingkungan alam yang relatif masih alami dengan kehidupan sosial budaya masyarakatnya yang penuh dengan kehangatan dan keramahan, menjadikan kota Bandung memiliki daya tarik wisata dengan atraksi wisata budaya lokal yang atraktif bagi para wisatawan. Keunikan ini juga memberikan kenyamanan dan kepuasan kepada pengunjungnya sehingga para wisatawan ingin melakukan kunjungan ulang ke Kota Bandung. Aspek kunjungan yang dilakukan wisatawan di Kota Bandung dengan pengalaman atas variasi atraksi wisatanya, lingkungan sosial budayanya, ketersediaan infrastruktur kota, aneka hiburan yang tersedia, kesejukan udaranya, maka tumbuh kesan yang sangat baik dan dapat membangkitkan keinginan untuk melakukan kunjungan ulang juga dapat memberikan suasana santai kepada wisatawan. Kesan baik atas pengalaman selama berkunjung di Kota Bandung ini menjadi faktor penentu bagi para wisatawan untuk merasakan kenyamanan dan kepuasan sehingga berdampak pada keinginan para wisatawan untuk melakukan kunjungan ulang ke Kota Bandung.

Dari penjelasan tentang citra kota dalam dukungan pengalaman berwisata atas atraksi wisata yang bervariasi, lingkungan sosial dan alam, dukungan infrastruktur, jenis hiburan yang disuguhkan, kesejukan alamnya, aspek budaya lokal berdampak pada tumbuhnya kesan yang positif dari wisatawan sehingga para wisatawan berkeinginan kembali untuk berkunjung ke Kota Bandung. Sangat jelas bahwa citra kota sangat erat berkaitan dengan keinginan berkunjung ulang. Semakin tinggi tingkat cintra kota memberikan kesan positif terhadap wisatawannya, maka semakin tinggi pula peluang bagi wisatawan untuk melakukan kunjungan ulang atau sebaliknya. Hal ini sejalan dengan penjelasan yang disampaikan oleh Echter dan Ritchie (2003) yang mengungkapkan bahwa citra kota berperan penting dalam memahami perilaku wisatawan dalam melakukan perjalanan (Echter dan Ritchie, 2003). Lebih jauh dikatakan bahwa citra akan berkaitan dengan kesan, pengetahuan emosi, nilai dan benefit dan perilaku konsumen. Keterkaitan citra dengan kesan, pengetahuan, emosi, nilai dan benefit, keduanya saling menguatkan bahwa citra berhubungan dengan pengetahuan, kesannya, nilai yang diperolehnya serta keuntungan yang dirasakannya yang dapat menentukan perilakunya dalam bentuk kunjungan ulang (Jenkins, 2009). Lebih lanjut dikatakan dalam bahasa yang berbeda bahwa citra destinasi wisata dianggap penting karena dapat menentukan keputusan wisatawan atas kepuasan selama berkunjung (Jenkins, 2009). Sementara pendapat lain dengan memberikan penjelasan yang lebih detail yang juga menguatkan keterkaitan citra kota dengan kunjungan ulang, mengatakan bahwa keterkaitan citra kota dengan keinginan berkunjung ulang dengan memaknai citra kota dengan kekuatannya dapat berperan besar untuk mengubah dan mengatur kembali kesan dan persepsi wisatawan di dalam menentukan destinasi 
yang akan dikunjungi (Banyai, Maria, 2009). Dari penjelasan tersebut dapat disampaikan bahwa citra kota berkaitan dengan tingkat kunjungan ulang wisatawan. Lebih lanjut dapat dikatakan bahwa sudut pandang wisatawan terhadap kota sebagai tujuan wisatanya akan bernilai positif atas pesan dan kesan yang diperolehnya, apabila kota tersebut dapat memberikan pengalaman yang baik bagi wisatawannya baik pada aspek variasi atraksi wisata, lingkungan sosial yang ramah dan kooperatif serta lingkungan alam yang sejuk, nilai budaya lokal yang diwujudkan melalui tumbuhnya kearifan lokal yang berdaya tarik wisata.

\section{KESIMPULAN}

Citra Kota Bandung yang dibangun melalui tingginya tingkat variasi atraksi wisata, lingkungan tradisi dan sosial budaya dengan keramahan dalam wujud "someah hade $\mathrm{ka}$ semah" yang sangat memuliakan wisatawan, dukungan infrastruktur yang cukup memadai sehingga menjadi daya dukung kepariwisataan, dan suguhan aneka jenis hiburan tradisional dapat memberikan kesan positif bagi pengalaman wisatawan sehingga menjadi faktor pendorong bahkan menjadi penentu dalam peningkatan kunjungan ulang wisatawan ke Kota Bandung. Sisi lain Citra Kota Bandung adalah lingkungan alam Kota Bandung yang masih tetap memberikan kesejukan sehingga menumbuhkan kenyamanan selama berkunjung ditambah dengan atraksi budaya lokal yang bernilai Internasional seperti "Saung Angklung Udjo" dapat memberikan kesan yang sangat baik sehingga membangkitkan keinginan untuk berkunjung kembali. Keinginan kunjungan ulang ini sebagai dampak dari pengetahuan yang menumbuhkan sikap positif menjadi pengalaman yang baik yang menumbuhkan kesan positif selama berkunjung, sehingga memberikan pesan bahwa Kota Bandung menjadi Kota yang menarik, akhirnya dapat membangkitkan keinginan wisatawan untuk melakukan kunjungan ulang.
Tingginya tingkat pengaruh citra kota yang dibangun melalui cognitive image, unique image, dan affective image terhadap kunjungan ulang, maka dapat disarankan bahwa Pihak Pemerintah Daerah melalui Dinas Kebudayaan dan Pariwisata Kota Bandung meninjau kembali kebijakan untuk meningkatkan anggarannya dalam pembangunan infrastruktur serta membangun kembali kesenian atau hiburan yang berbasis budaya tradisional untuk lebih meningkatkan daya tarik dan dapat meningkatkan kunjungan ulang. pada aspek akademis, disarankan bagi peneliti selanjutnya untuk dapat melakukan penelitian dengan memadukan citra kota dengan aspek lain yang juga dapat berhubungan dengan kunjungan ulang, untuk dapat menentukan skala prioritas pembangunan pariwisata yang berbasis kebutuhan.

\section{DAFTAR PUSTAKA}

Banyai, M. (2009). The Image of Tourism Destinations: A Case of Dracula Tourism. Waterloo, Ontario, Canada.

Dinas Kebudayaan dan Pariwisata Kota Bandung, Tahun 2016.

Dinas Kebudayaan dan Pariwisata Kota Bandung, Tahun 2018.

Hailin. (2016). Hailin Qu, et all. 2010. A Model of Destination Branding: Integrating The Concept of The Branding and Destination Image. Journal homepage: www. elsevier.com Jenkins, O. H. (2009). Understanding and Measuring Tourist Destination Images. Australian Housing and Urban Research Institute, University of Queensland, St Lucia, QLD 4072, Australia, 4072.

Kotler, P. and K. (2012). Marketing Management, 14th Global Edition. England: Pearson.

Marketing, O. (2016). Marketing Outlook, Tahun 2018.pdf.

Martinez. (2010). Factor Influenching Repeat Visits to a Destination: The Influence of Group Composition. 
Journal homepage: www. elsevier.com.

Rasyid, H. Al. (2005). Hand Out Kuliah Statistika. Bidang Kajian Utama Ilmu Pemerintahan Kerjasama Universitas Padjadjaran dan Institut Ilmu Pemerintahan.

Ritchie. (2003). The Meaning and Mesurement of Destinatin Image. The Journal of Tourism Studies 14(1), Canada.

Singarimbun, M. dan S. E. (2004). Metode Penelitian Survey. LP3S Jakarta.

Syarifuddin, D. (2016). Nilai Wisata Budaya Seni Pertunjukan Saung Angklung
Udjo Kota Bandung, Jawa Barat, Indonesia. Jurnal Manajemen Resort dan Leisure, 13(2), hlm. 53-60. https://doi.org/10.17509/JUREL.V13I 2.4979

Syarifuddin, D. (2017). Nilai Budaya Batik Tasik Parahiyangan Sebagai Daya Tarik Wisata Jawa Barat. Jurnal Manajemen Resort Dan Leisure, 14(2), hlm. 9-19.

Syarifuddin, D. (2018). Pasar Tradisional Dalam Perspektif Daya Tarik Wisata. Jurnal Manajemen Resort Dan Leisure, 15(1), hlm. 19-32. 